\title{
STUDY OF NUTRIENT POLLUTANTS AND THEIR IMPACTS ON THE WATER QUALITY OF THE MINDU RESERVOIR AT MOROGORO MUNICIPALITY
}

\author{
Consolatha J. Ngonyani ${ }^{1}$ and Hudson H. Nkotagu ${ }^{2}$ \\ ${ }^{1}$ = Ngonyani Consolatha, J., University of Dar es Salaam CoET Chemical and Process Engineering, \\ P.O. Box 35131 Dar Es salaam Tanzania (konsolatha@yahoo.com). \\ ${ }^{2}=$ Nkotagu, H. H., University of Dar Es Salaam, Faculty of Science, Geology Department, \\ P. O. Box 35052, Dar Es Salaam, Tanzania (hudson@.udsm.ac.tz).
}

\begin{abstract}
The physical-chemical parameters characterization of Mindu Reservoir, whose 50\% of its waters is being plagued by aquatic weeds, involved the analyses of water and sediment samples that were collected during the dry season. As the nutrients levels of Mindu waters were determined, phosphorous (TP- $\mathrm{PO}_{4}{ }^{3-}$ ) levels were found to be high enough for supporting eutrophication process. Likewise Nitrogen/Phosphorous ratios average of $8.51 \pm 4.32$ suggested a Redfield behavior of nutrients with nitrogen being a limiting one. The dominant clay minerals of the Mindu surficial sediments were found to be kaolin and illite, where as the Cation Exchange Capacity values were found to be high enough for the sorption of nutrients and pollutants. Both river inflows, overlay-flows and sediments forms the mode of transport of nutrient, with the later behaving as sinks of nutrients through out the year. The evaporation, bio-geo-chemical and Nitrogen fixation processes along with macrophyte productivity, support the hypotheses that physical-bio-geo-chemical processes influences the spatial distribution of major ion in the Mindu Reservoir. These findings classify Mindu as eutrophic, calcium magnesium bicarbonate type. A detailed multidisciplinary study that involves more than one year cycle was recommended, to capture inter seasonal variability, and for the modeling of the sequestration of nutrients in various trophic levels.
\end{abstract}

Key words: Mindu reservoir, eutrophication, Redfield ratio, macrophyte, downstream evaporation hydro biogeochemistry.

\section{INTRODUCTION}

Mindu water reservoir was constructed with the aim of solving water shortages and to control flow on the Ngengere River (MOWASA, 2001). Currently it is the major water source, supplying more than $90 \%$ of domestic and $70 \%$ of industrial water requirements for Morogoro municipality. However, within the 18 years since its construction $50 \%$ of its volume has been invaded by macrophytes, e.g. water lilies (Nymphaea sp), musk grass (Chara sp) horntail and (Ceratophyllum demersum, L). The Reservoir has also been impacted by various anthropogenic activities (Sibuga, 1997; Mbago, 1999; MOWASA, 2001). None of the previous studies has made the quantitative assessment of nutrients levels of the entire Reservoir in relation to the current macrophyte invasion. This paper aims at discussing the status of nutrient pollution of Mindu Reservoir and its impacts on both water quality and the macrophyte invasion levels.

\section{GENERAL DESCRIPTION OF MINDU RESERVOIR}

Mindu Reservoir is located $500 \mathrm{~m}$ above sea level, between latitudes $6^{\circ} 51^{\prime} \mathrm{S}$ to $6^{\circ} 52^{\prime} \mathrm{S}$ and longitudes $37^{\circ} 30^{\prime} \mathrm{E}$ to $37^{\circ} 40^{\prime} \mathrm{E}$, southeast of Ngerengere River, about $7 \mathrm{~km}$ from Morogoro town; has both the surface and catchments areas of 0.2224 and approximately $303 \mathrm{~km}^{2}$ respectively. The Reservoir's deepest point measures at $12 \mathrm{~m}$ during the rain season. The evaporation is $5 \mathrm{~mm}$ per day ( $0.5 \%$ of total volume per annum) while siltation rate measures at $0.5 \%$ of total volume per annum (MOWASA 2001). The inflowing and out flowing Rivers are clearly shown in (Figure 1). Similarly Mindu geology, climate and land use are well covered by several authors (Sampson and Wright, 1964; Rapp et. al., 1973). A very long dry period between June and October, and persistent afternoon hot-dry local breezes and strong SE trade winds of June to September gradually displaces surface waters (towards the outlet), in a manner that they modify the hydraulic retention times and causes nutrients re-suspensions the phenomenon that has been explained in work by Verburg and Hecky, (2003). Mindu Reservoir's water is maintained almost entirely by surface water from inflowing Rivers that passes through the nearby suburban habitat/villages, paddy fields and the Mzinga military industrial complex. The Reservoir vegetations seen during the dry season included aquatic macrophytes and algae (Plate 1). The most 
abundant seen were horntail (Ceratophyllum demersum, L), musk grass (Chara species), water lilies (Nymphae sp) mosquito fern (Azolla sp.), water spinach (Ipomoea aquatica, Forsk.), water cabbage (Pistia statiotes, L), Knotweed (Polygonum Senegalese Meisn), reeds (Phragmites sp.) and cattail (Typha latifolia). Some were also reported in Sibuga, (1997) and Mbago, (1999).

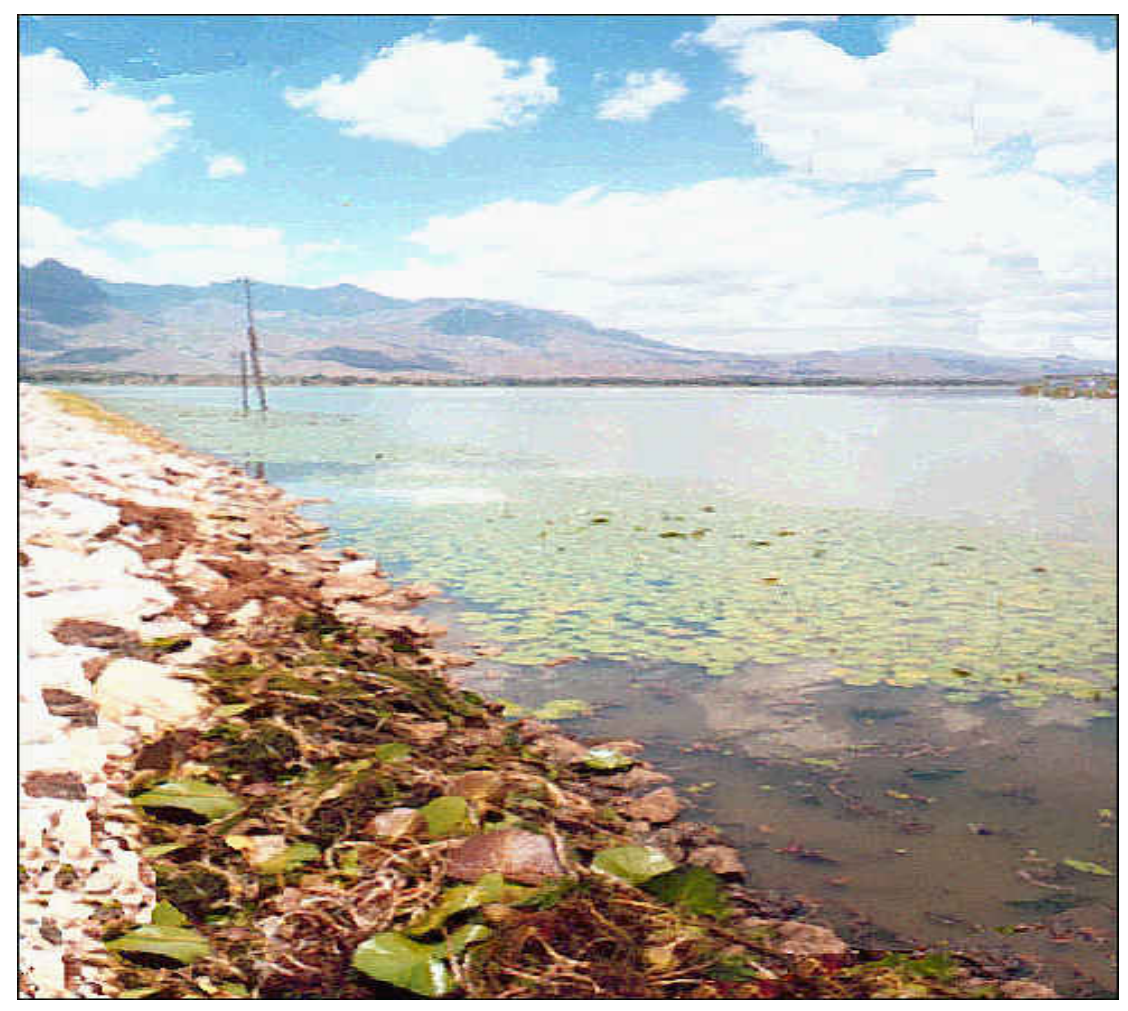

Plate 1 Northeast zone engulfed with both floating and submersed macrophytes that is water lilies (Nymphaea $s p$ ), mosquito fern (Azolla sp) and horntail (Ceratophyllum demersum, L).

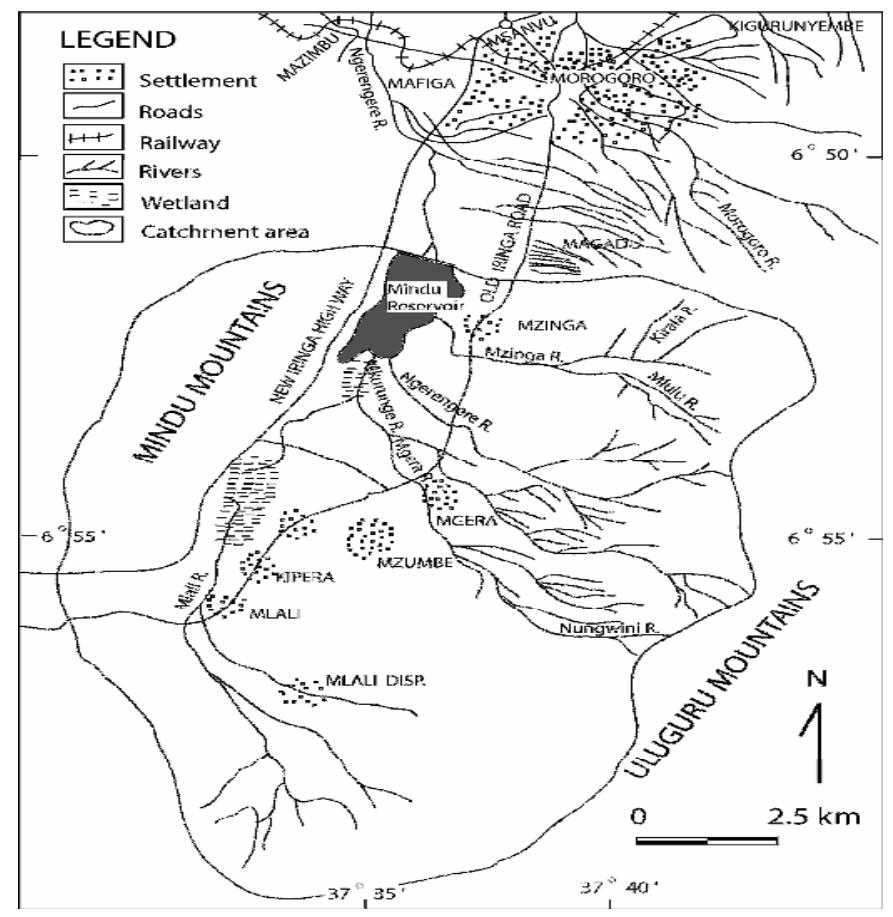

Figure 1 Location map of Mindu Reservoir and its surroundings 


\section{MATERIALS AND METHODS}

A portable geographical positioning system (GPS) unit was used to locate relative distance from River entry points (Figure 2). A three-dimension watersampling regime was instituted and four sampling zones demarcated as A, B, $\mathbf{C}_{\mathbf{1}}, \mathbf{C}_{\mathbf{2}}$ and $\mathbf{D}$. A standard 1.5-liter Van Dorn water and Peterson grab samplers were used for water and sediment sampling consecutively during the dry season (between10 am and 1 p.m). The analysis of the $\mathrm{pH}, \mathrm{EC}, \mathrm{DO}$ and Turbidity - NTU were done in situ, using a portable field probes by HANNA Scientific instruments (UK) (APHA, 1995). One liter water samples were filtered through $0.45 \mu \mathrm{m}$ glass fiber filter paper (Whatman ${ }^{\circledR} \mathrm{GF} / \mathrm{C}$ ), residue and filter paper were soaked in a darkened-test-tube containing $5 \mathrm{ml}$ acetone and stored in a cool box for subsequent chlorophyll-a determinations (APHA, 1995). The filtered samples were preserved with conc. $\mathrm{HCl}$ drops (cations) and unfiltered samples in clean 1 liter sampling nalgene bottles, preserved using $1 \mathrm{ml}$ chloroform per liter of water, transported to SUA laboratory and water analyses performed the same day (anions). Atomic Absorption - Spectrometric methods (cations); Flame emission spectrometric methods $\left(\mathrm{Na}^{+}+\mathrm{K}^{+}\right)$; other parameters alkalinity, (titrimetric); $\mathrm{SO}_{4}{ }^{2-}$ ( $\mathrm{Ba}\left(\mathrm{ClO}_{4}\right)_{2}$ method); $\mathrm{NO}_{3}{ }^{-}$(Ion Selective Electrode); TN, (KJeldahl); OC, (wet oxidation); $\mathrm{Cl},(\mathrm{Ag} \mathrm{NO}$ ); both methods by (APHA, 1995). As a peristaltic pump was used for pore water samples, one $\mathrm{kg}$ composite sediment samples from 11 representative sampling points, was air dried crushed and sieved using standard ASTM set of sieves with (mesh sizes $63 \mu \mathrm{m}-2 \mathrm{~mm}$ ). The Andersen pipette was used in clay fractionation and clay mineral determinations undertaken on particle sizes $2-20 \mu \mathrm{m}$ and $>63$ micron fractions, using the $\mathrm{XRD}$ and XRF respectively (Klute, 1986); parameters $\mathrm{OC}, \mathrm{SO}_{4}{ }^{2-}$ and $\mathrm{NO}_{3}^{-}$(APHA, 1995). Heavy metal content of sediments was determined using XRF technique for elements $\mathrm{Co}, \mathrm{Cu}, \mathrm{Mn}, \mathrm{Mo}$, $\mathrm{Fe}, \mathrm{Pb}$ and $\mathrm{Zn}$ (Klute, 1986); the facility that was located at the Southern and Eastern Africa Mineral Center in Dar es Salaam. Data analysis was done as per Davis, (2002).

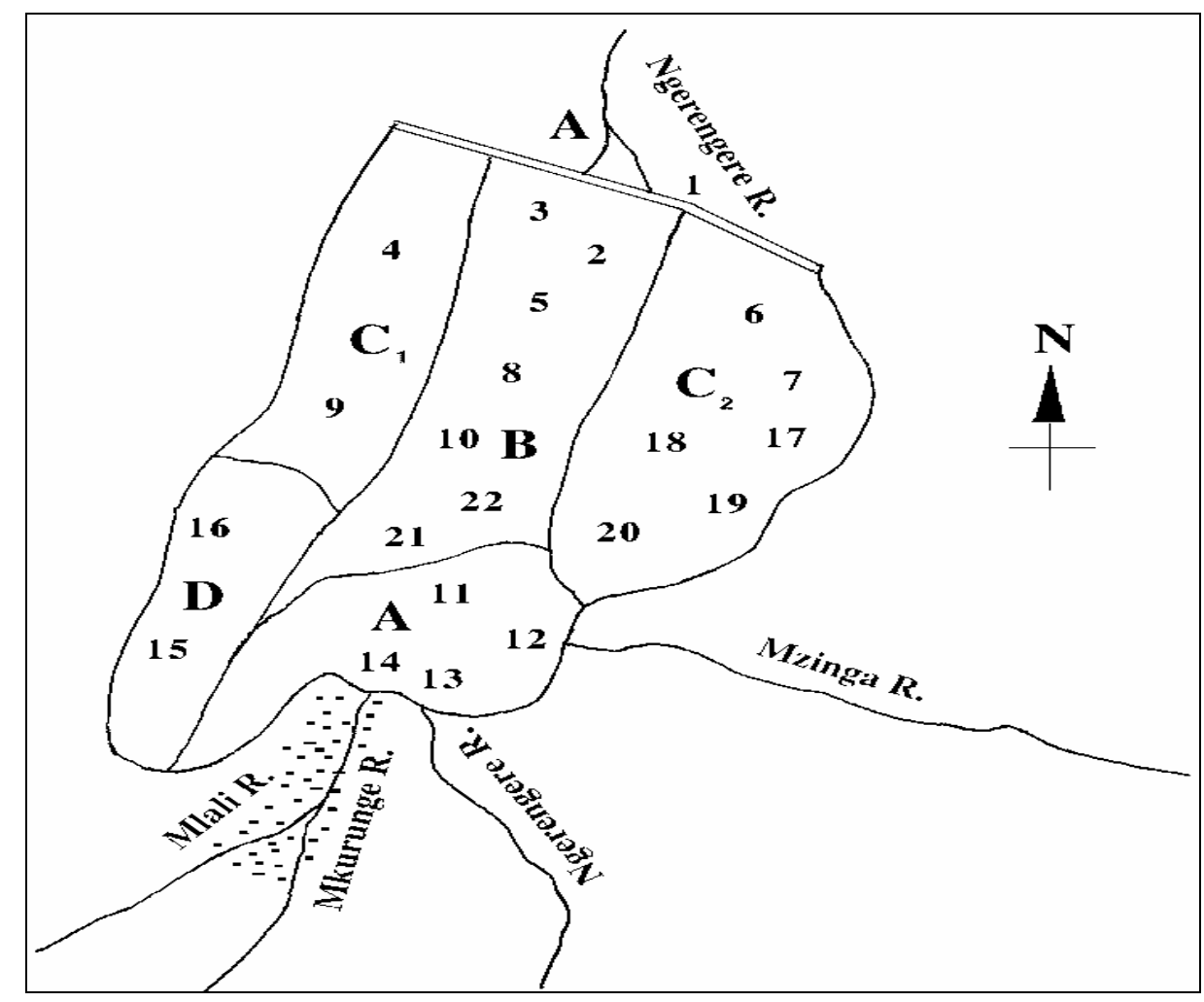

Figure 2 Water and sediment sampling point sketch: (zone A) represents the inflowing rivers Mlali, Mkulunge, Ngerengere and Mzinga; the spillway and out-flowing points. (Zone B) represents the old riverline and lacustrine zone; (zone $\mathbf{C}_{\mathbf{1}}$ ) incorporates the macrophytes stands of the northwest $(\mathrm{NW})$; (zone $\mathbf{C}_{2}$ ) represents the densely macrophytes of northeast (NE), east (E) and southeast (SE); zone (D) the fish landing and village location. 


\section{RESULTS AND DISCUSSIONS}

\section{Eutrophication of Mindu Reservoir}

Phosphate and nitrate averaged at $(0.05 \pm 0.03)$ and $(0.44 \pm 0.08) \mathrm{mg} / \mathrm{l}$ respectively, suggesting that the Reservoir was already eutrophic. Mindu surface waters productivity involved various macrophyte species and algae communities. The average value for Chlorophyll-a, were measured at $4 \pm 0.03 \mu \mathrm{g} / \mathrm{l}$, which strongly reflected high blue green productivity. The N; $\mathrm{P}$ ratios values averaged $8.51 \pm$ 4.3 and followed a Redfield behavior with $\mathrm{N}$ as a limiting nutrient (Table 1). The observed slight variation at Mzinga Ngerengere and Mlali/Mkurunge Rivers could just be statistically insignificant, due to small sample size for each trend line $(\mathrm{n}=3)$. However, invariable and yet low $\mathrm{HCO}_{3}{ }^{-}$ levels at the Reservoir outlet could be due to low photosynthesis rates and high mixing.

Table 1: Descriptive statistics of Mindu dam waters during the dry season

\begin{tabular}{|c|c|c|c|c|c|c|}
\hline & & Minimum & Maximum & Mean & & Std. Dev \\
\hline & units & Statistic & Statistic & Statistic & Std. Error & Statistic \\
\hline Distance & $\mathrm{km}$ & 0.01 & 3,00 & 1.36 & 0.10 & 0.88 \\
\hline Depth & $\mathrm{m}$ & 0,00 & 8,00 & 1.36 & 0.21 & 1.81 \\
\hline $\mathrm{pH}$ & - & 7.5 & 9.5 & 8.76 & 0.05 & 0.44 \\
\hline $\mathrm{Temp}$ & - & 23.5 & 28.9 & 26.15 & 0.22 & 1.84 \\
\hline $\mathrm{EC}$ & $\mathrm{mS} / \mathrm{Cm}$ & 1.76 & 1.99 & 1.926 & 0.01 & 0.05 \\
\hline Turb & $\mathrm{NTU}$ & 2.78 & 57.48 & 11.08 & 1.24 & 10.6 \\
\hline $\mathrm{TDS}$ & $\mathrm{mg} / \mathrm{l}$ & 88,00 & 107,00 & 101.43 & 0.45 & 3.86 \\
\hline $\mathrm{DO}$ & $\mathrm{mg} / \mathrm{l}$ & 3.23 & 9.35 & 6.33 & 0.14 & 1.21 \\
\hline $\mathrm{TP}$ & $\mathrm{mg} / \mathrm{l}$ & 0.01 & 0.07 & 0.02 & 0,00 & 0.01 \\
\hline $\mathrm{CO}_{3}{ }^{2-}$ & $\mathrm{mg} / \mathrm{l}$ & 2.2 & 19.8 & 6.96 & 0.44 & 3.76 \\
\hline $\mathrm{HCO}_{3}{ }^{-}$ & $\mathrm{mg} / \mathrm{l}$ & 180,00 & 359.9 & 250.04 & 4.52 & 38.61 \\
\hline $\mathrm{TC}^{2-}$ & $\mathrm{mg} / \mathrm{l}$ & 10,00 & 13,00 & 10.63 & 0.10 & 0.83 \\
\hline $\mathrm{SO}_{4}{ }^{2-}$ & $\mathrm{mg} / \mathrm{l}$ & 0.24 & 11.58 & 2.15 & 0.22 & 1.87 \\
\hline $\mathrm{Mg}^{2+}$ & $\mathrm{mg} / \mathrm{l}$ & 6.08 & 17.12 & 8.18 & 0.24 & 2.04 \\
\hline $\mathrm{Ca}^{2+}$ & $\mathrm{mg} / \mathrm{l}$ & 14.08 & 19.05 & 18.2 & 0.10 & 0.84 \\
\hline $\mathrm{Na}^{+}$ & $\mathrm{mg} / \mathrm{l}$ & 1,00 & 16.9 & 12.79 & 0.27 & 2.32 \\
\hline $\mathrm{K}^{+}$ & $\mathrm{mg} / \mathrm{l}$ & 1.62 & 3.81 & 2.38 & 0.05 & 0.47 \\
\hline $\mathrm{TN}^{-}$ & $\mathrm{mg} / \mathrm{l}$ & 0.05 & 0.19 & 0.102 & 0.002 & 0.018 \\
\hline $\mathrm{NO}_{3}{ }^{-}$ & $\mathrm{mg} / \mathrm{l}$ & 0.21 & 0.81 & 0.439 & 0.009 & 0.076 \\
\hline $\mathrm{SiO}_{2}$ & $\mathrm{mg} / \mathrm{l}$ & 3.65 & 11.43 & 7.123 & 0.196 & 1.672 \\
\hline $\mathrm{PO}_{4}{ }^{3-}$ & $\mathrm{mg} / \mathrm{l}$ & 0.02 & 0.21 & 0.048 & 0.004 & 0.032 \\
\hline $\mathrm{N} / \mathrm{P}^{-}$ & - & 1.74 & 31.66 & 8.51 & 0.61 & 4.32 \\
\hline $\mathrm{Chll}^{-\mathrm{a}}$ & $\mathrm{mg} / \mathrm{l}$ & 0.002 & 0.007 & 0.004 & 0,000 & 0.002 \\
\hline
\end{tabular}

\section{Mindu Reservoir Water's Hydro Geo Chemical Properties}

Mindu Reservoir waters were hence defined as calcium magnesium bicarbonate type (Table 2). Reservoir waters were found to be ideal for the normal physiology of most aquatic plants and animals. Varieties of surface, benthic and submerging macrophytes for example mosquito fern (Azolla sp.), horntail (Ceratophyllum demersum, L), musk grass (Chara species), water lilies (Nymphae $s p$ ) water spinach (Ipomoea aquatica, Forsk.), water cabbage (Pistia statiotes, L), Knotweed (Polygonum Senegalese Meisn), reeds (Phragmites sp.) and cattail (Typha latifolia) were clearly seen. Aquatic animals for example ducks and fowls were in abundances in areas with dense macrophyte stands (south and south east zones). Various snails' species including Biomphalaria pfeifferi Krauss species were rampaging during the sampling expeditions. Such snails are associated with the frequent Bilharzias epidemic threats among Mindu populations which was also reported by Nduku and Harrison (1976) 
Table 2: Mindu waters compared to representatives of African surface waters

\begin{tabular}{|c|c|c|c|c|c|c|c|c|c|}
\hline & Cond $(\mathrm{K} 20)$ & $\mathrm{Na}^{+}$ & $\mathrm{K}^{+}$ & $\mathrm{Ca}^{2+}$ & $\mathrm{Mg}^{2+}$ & $\mathrm{SO}_{4}{ }^{2}-$ & $\mathrm{Cl}^{-}$ & $\begin{array}{l}\mathrm{HCO}_{3}^{-} \\
\mathrm{CO}_{3}{ }^{2-}\end{array}$ & Units \\
\hline \multicolumn{10}{|l|}{ COMMON } \\
\hline \multirow[t]{2}{*}{ Kagera } & \multirow[t]{2}{*}{85.6} & 7.1 & 3.4 & 5.0 & 3.9 & 5.1 & 3.7 & 48.0 & $\mathrm{mg} / 1$ \\
\hline & & 0.309 & 0.087 & 0.250 & 0.321 & 0.106 & 0.104 & 0.786 & me /l \\
\hline \multicolumn{10}{|c|}{ SODIUM CHLORIDE } \\
\hline \multirow[t]{2}{*}{ Singida } & \multirow[t]{2}{*}{5740} & 1240 & 10.0 & 56.4 & 68.8 & 140.0 & 1890 & 345 & $\mathrm{mg} / \mathrm{l}$ \\
\hline & & 53.94 & 0.256 & 2.814 & 5.663 & 2.915 & 53.31 & 5.66 & me /1 \\
\hline \multicolumn{10}{|c|}{ DILUTE SODIUM BICARBONATE } \\
\hline \multirow[t]{2}{*}{ Enchanted } & \multirow[t]{2}{*}{27.5} & 6.6 & 0.8 & 0.2 & 0.0 & 0.1 & 0.6 & 17.7 & $\mathrm{mg} / 1$ \\
\hline & & 0.287 & 0.022 & 0.010 & 0.002 & 0.002 & 0.017 & 0.290 & me $/ 1$ \\
\hline \multicolumn{10}{|c|}{ CONCENTRATED SODIUM BICARBONATE } \\
\hline \multirow[t]{2}{*}{ Nanyuki+Njek } & \multirow[t]{2}{*}{1758} & 460 & 84.0 & 7.6 & 2.1 & 130.0 & 91.0 & 951 & $\mathrm{mg} / 1$ \\
\hline & & 20.00 & 2.148 & 0.379 & 0.173 & 2.707 & 2.567 & 15.6 & me $/ 1$ \\
\hline \multicolumn{10}{|c|}{ SODIUM - POTASSIUM - MAGNESIUM BICARBONATE } \\
\hline \multirow[t]{2}{*}{ Katanda } & \multirow[t]{2}{*}{393.0} & 14.0 & 19.5 & 18.2 & 35.0 & 8.9 & 6.2 & 283.1 & $\mathrm{mg} / 1$ \\
\hline & & 0.609 & 0.499 & 0.908 & 2.881 & 0.185 & 0.175 & 4.64 & me $/ 1$ \\
\hline \multicolumn{10}{|c|}{ **CALCIUM - MAGNESIUM BICARBONATE } \\
\hline \multirow[t]{2}{*}{ Wisila } & \multirow[t]{2}{*}{350.0} & 7.5 & 2.0 & 41.9 & 22.4 & 9.7 & 4.5 & 252.6 & $\mathrm{mg} / 1$ \\
\hline & & 0.326 & 0.051 & 2.091 & 1.844 & 0.202 & 0.127 & 4.14 & me $/ 1$ \\
\hline \multicolumn{10}{|c|}{ UNUSUAL SPRINGS } \\
\hline \multirow[t]{2}{*}{ Shatanda } & \multirow[t]{2}{*}{1980} & 394.0 & 15.0 & 59.0 & 0.6 & 613.0 & 209.0 & 104.0 & $\mathrm{mg} / 1$ \\
\hline & & 17.14 & 0.384 & 2.944 & 0.050 & 12.77 & 5.895 & 1.71 & me $/ 1$ \\
\hline \multicolumn{10}{|c|}{ ** (CALCIUM - MAGNESIUM BICARBONATE) } \\
\hline \multirow[t]{2}{*}{$\begin{array}{l}\text { Mindu- } \\
\text { Average }\end{array}$} & \multirow{2}{*}{$193 \pm 05.0$} & $\begin{array}{r}12.82 \\
\pm 2.32 \\
\end{array}$ & $\begin{array}{r}2.39 \\
\pm 0.47 \\
\end{array}$ & $\begin{array}{r}18.21 \\
\pm 0.84 \\
\end{array}$ & $\begin{array}{r}8.27 \\
\pm 2.04 \\
\end{array}$ & $\begin{array}{r}10.63 \\
\pm 0.83 \\
\end{array}$ & $\begin{array}{r}11.58 \\
\pm 1.85 \\
\end{array}$ & $256.03 \pm 38.6$ & $\begin{array}{l}\mathrm{mg} / \mathrm{l} \\
{ }^{*}=\mu \mathrm{S} / \mathrm{cm}\end{array}$ \\
\hline & & $\begin{array}{r}0.56 \\
\pm 0.08 \\
\end{array}$ & $\begin{array}{r}0.06 \\
\pm 0.12 \\
\end{array}$ & $\begin{array}{r}0.90 \\
\pm 0.04 \\
\end{array}$ & $\begin{array}{r}0.67 \\
\pm 0.19 \\
\end{array}$ & $\begin{array}{r}0.05 \\
\pm 0.04 \\
\end{array}$ & $\begin{array}{r}0.303 \\
\pm .024 \\
\end{array}$ & $4.25 \pm 0.68$ & me $/ 1$ \\
\hline
\end{tabular}

\section{** Two rows compared}

$\begin{aligned} & \text { Physicochemical Characteristics Mindu } \\ & \text { Reservoir Waters }\end{aligned}$
$\begin{aligned} & \text { The three dimensional (surface waters, across the } \\ & \text { the bottom waters in regions with high biodiversity } \\ & \text { and massive macrophyte stands that were }\end{aligned}$
$\begin{aligned} & \text { represented by sampling sites } 17 \text { and } 10 \\ & \text { clearly observed for the parameters; Turbidity } \\ & \text { (turb), Total Dissolved Substances (TDS), Electrical } \\ & \text { conductivity (EC), pH, Dissolved Oxygen (DO) and } \\ & \text { phosphate }\left(\mathrm{PO}_{4}{ }^{3-}\right) .\end{aligned}$


This indicated the prevailed anoxic conditions of the deep lacustrine zones. However the measured lower
DO levels at the southeast zone could be due to decomposition of biomass (Figure 4).

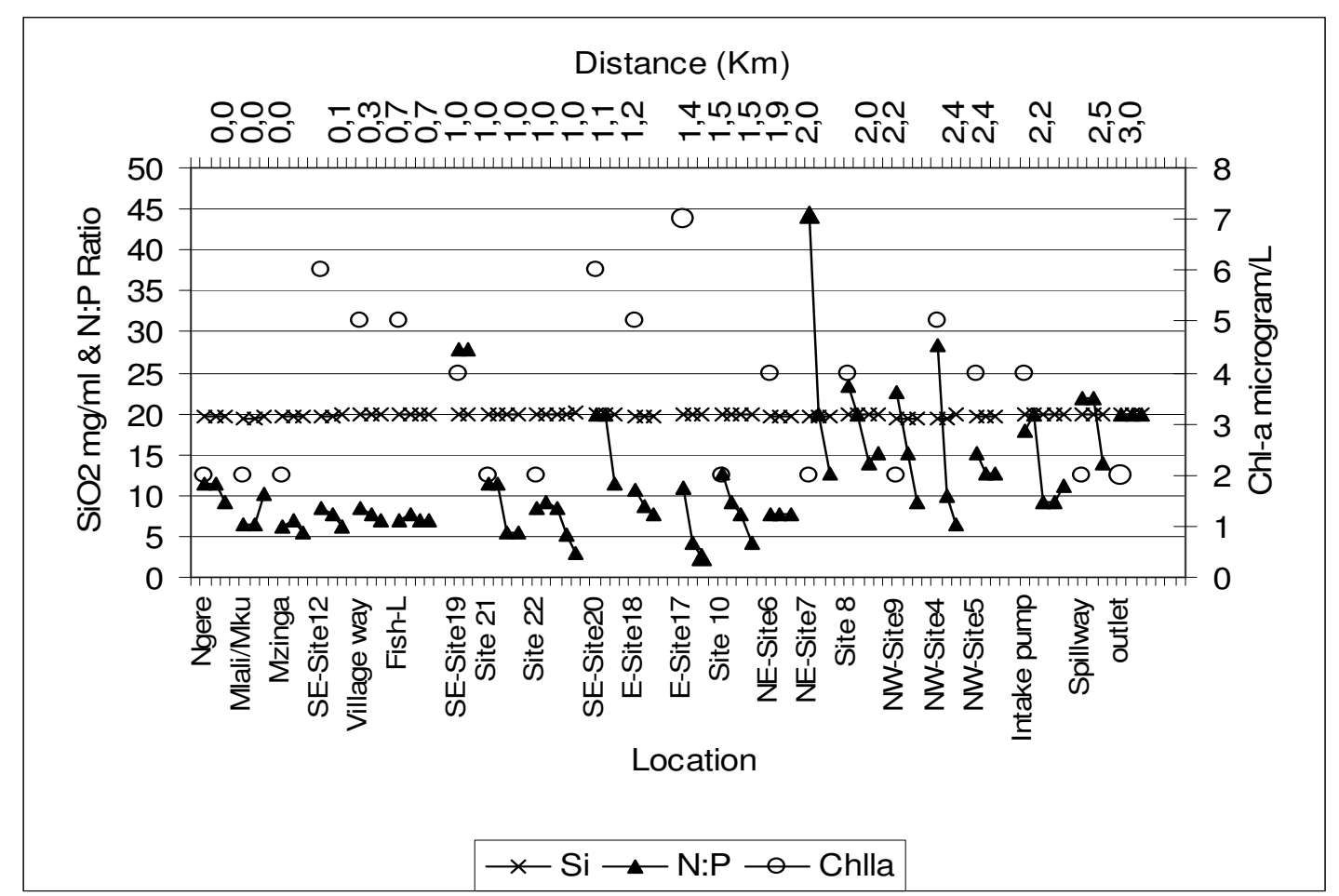

Figure 3 the spatial variations in levels of Nitrogen/Phosphorous ratio (N/P), Silica $\left(\mathrm{SiO}_{2}\right)$ and chlorophyll-a (Chll-a).

Slight water column stratification was evident in lacustrine zone at sampling sites 8 and 10 probably due to; temperature and density differences between (incoming and resident waters). Highest levels in Chlorophyll-a (Chll-a), was observed in east tern and south eastern macrophyte infested zones. These values also corresponded with moderate to low N/P ratios, which suggested a very high productivity trend during that season. However some irregularity in N/P ratios were observed at the South East zone could also be due to phosphorous loading from aquatic fowl wastes guano breeding grounds just near the Ngerengere inflowing zone (Figure 4).
High $\mathrm{Ca}^{2+}$ levels at lacustrine zone (sites 8, 10, 21 and 22) are associated by inputs from decomposing shells washed from the breeding zones by bottom currents. This is supported by the snail shells deposits that were found there. Decrease in $\mathrm{Mg}^{2+}$ and $\mathrm{Ca}^{2+}$, with depth at the (South East macrophyte infested zone) suggested nutrients utilization by macrophytes (Figure 5). The observed slight variation at Mzinga Ngerengere and Mlali/Mkurunge Rivers could just be statistically insignificant, due to small sample size for each trend line $(n=3)$. However invariable and yet low $\mathrm{HCO}_{3}{ }^{-}$ levels at the Reservoir outlet could be due to the respective low photosynthesis rate that has been hampered by the relatively higher Reservoir's flowing rate, at the outflow. 


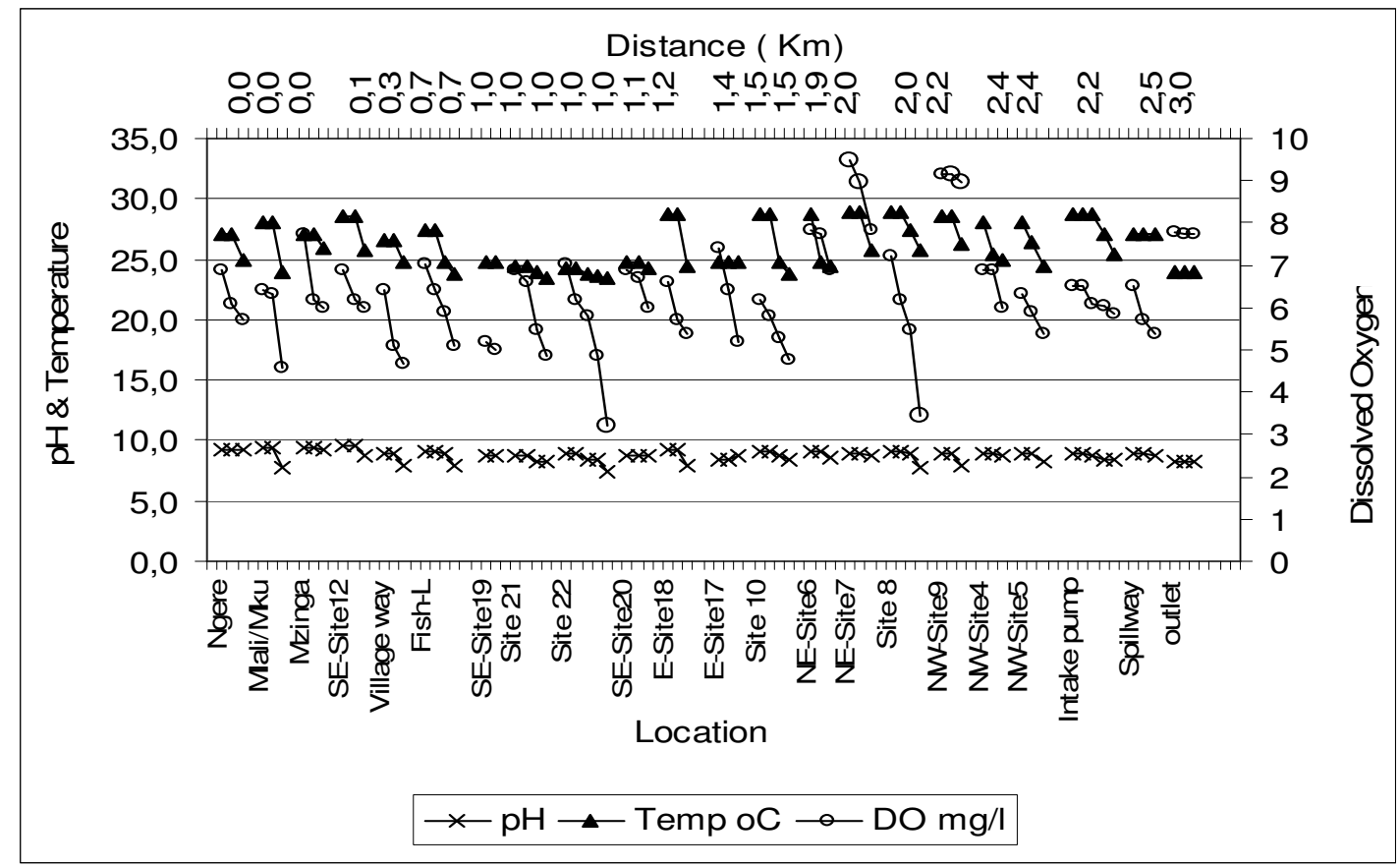

Figure 4 the spatial variations in Mindu Reservoir's physical parameters $\mathrm{pH}$, Temperature (Temp) \& Dissolved Oxygen (DO).

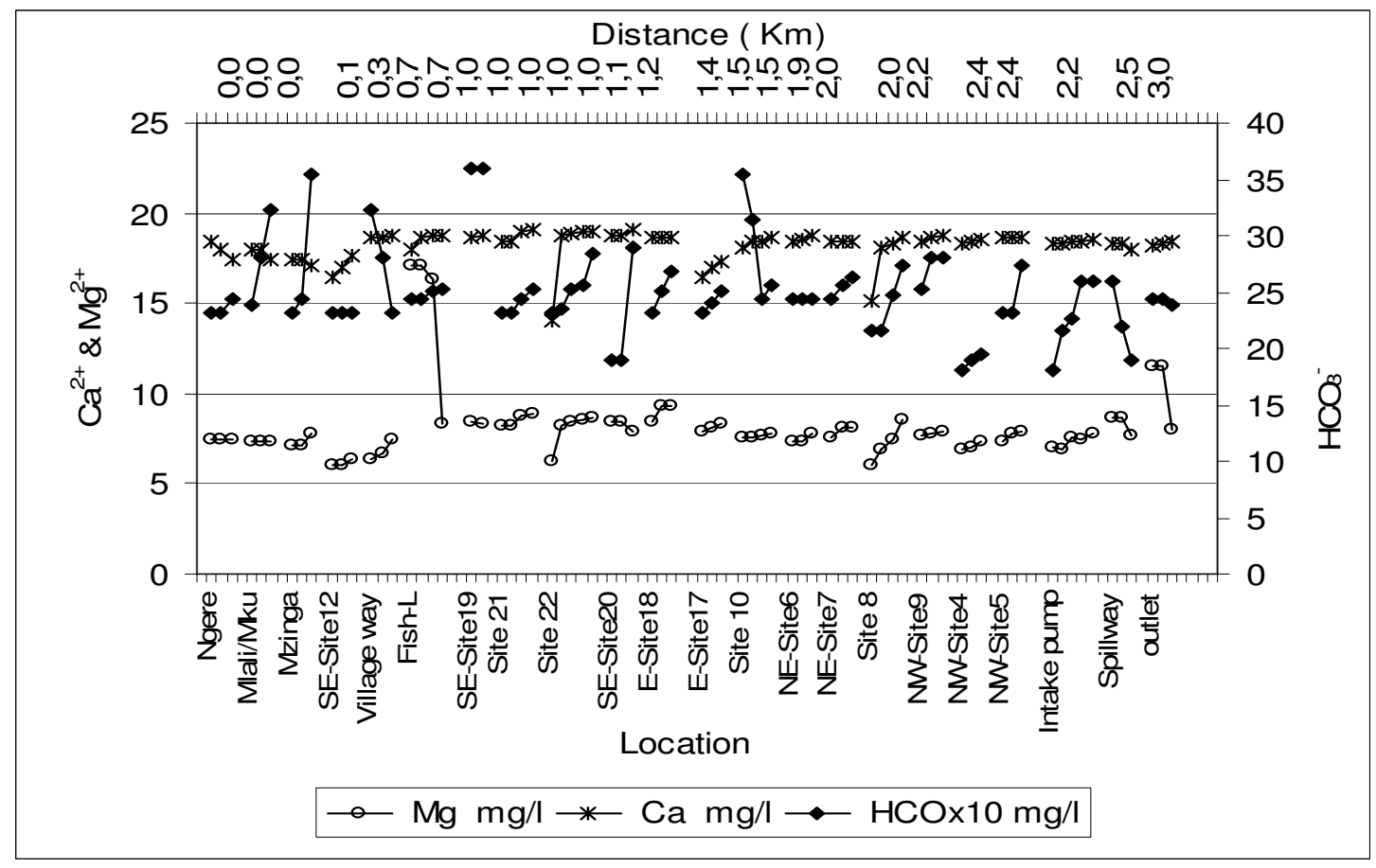

Figure 5 the spatial variations in levels of Magnesium $(\mathrm{Mg})$, Calcium $(\mathrm{Ca})$ and bicarbonate $\left(\mathrm{HCO}_{3}\right)$.

\section{Sediments Characteristics in Respect to Nitrogen and Phosphorous loading}

As high $\mathrm{pH}, \mathrm{EC}$ and $\mathrm{CEC}$ values in macrophyte and in-flowing Rivers zones coincided with the deposition of dominant clay minerals kaolin and illite (Ngonyani, 2003). The comparatively low $\mathrm{pH}$ in deep zone sediments were found to be due to sulfur mineralization, where as TN levels in sediments of both the inflowing Rivers was linked to the anthropogenic reasons (Figures 6 and 7) 


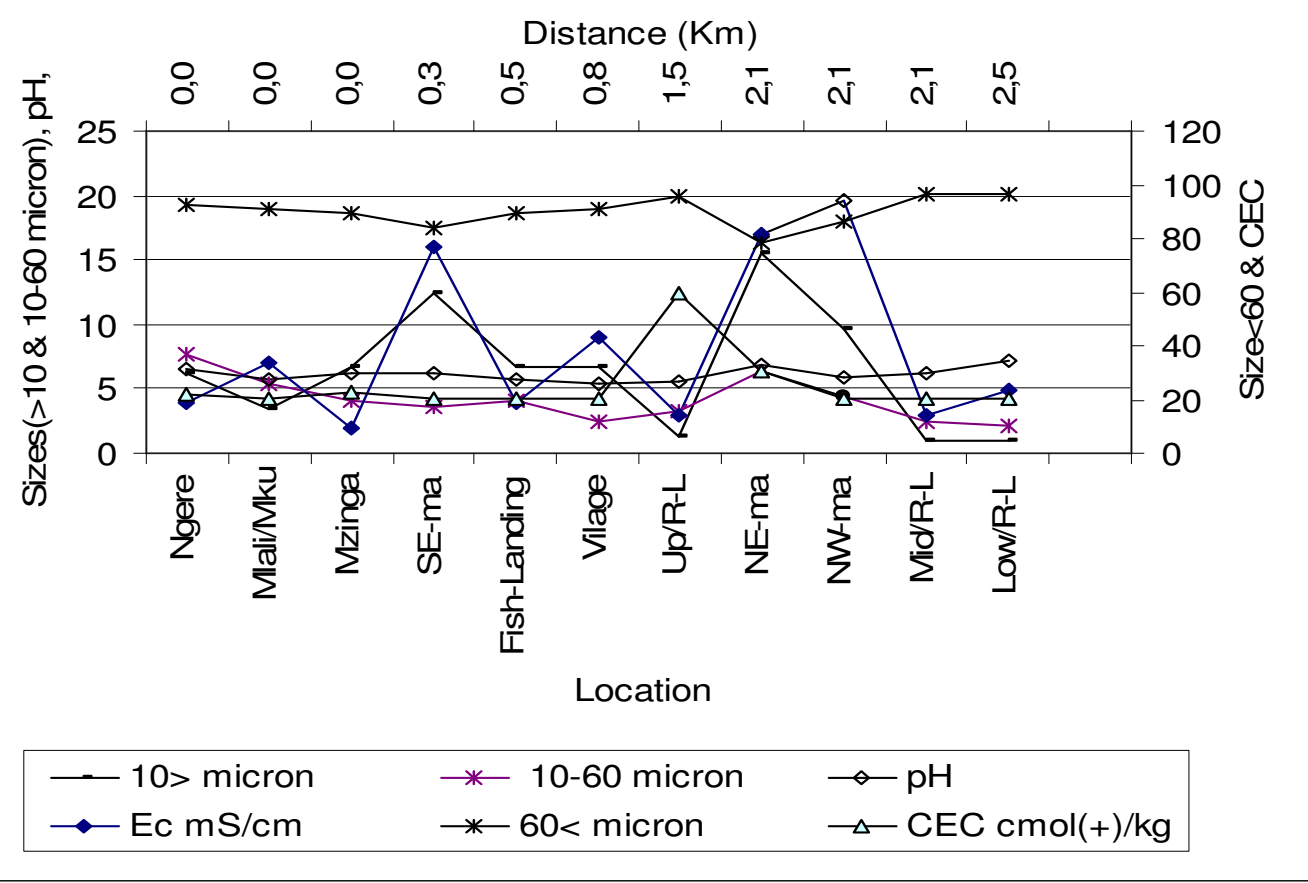

Figure 6 Cation Exchange Capacity (CEC), pH, Electric conductivity (EC) Level and sediment particle sizes variations with sampling locations.

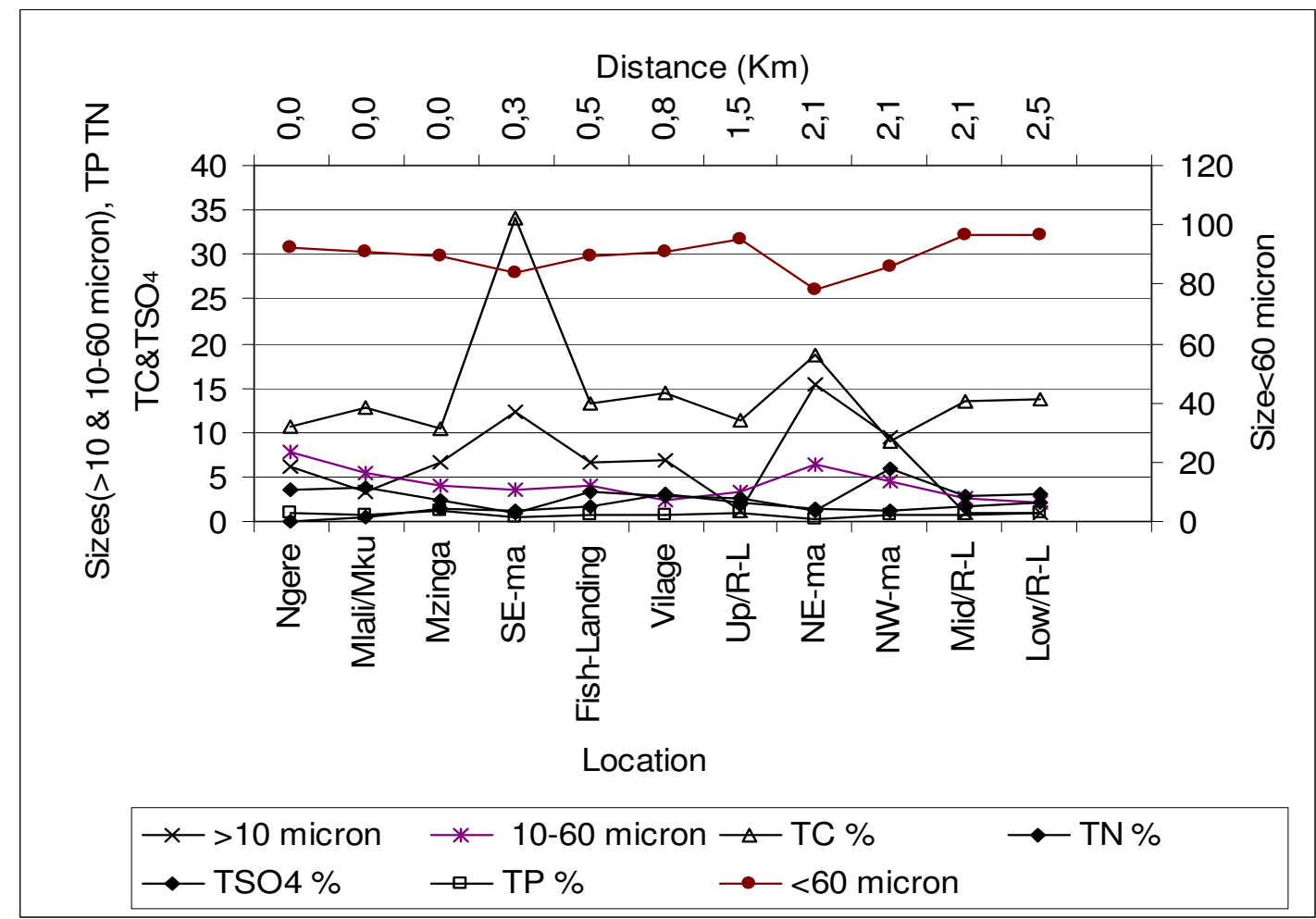

Figure 7 Nutrients Total Nitrogen (TN), Total carbon (TC), Total Sulphur $\left(\mathrm{TSO}_{4}\right)$,

Total Phosphorous (TP) and sediment particle sizes variations with sampling locations 


\section{Chemical Ecology of Mindu Waters in Respect to the Eutrophication}

From these findings chemical ecology of Mindu Reservoir depends on the bio-geo chemical processes. The alkaline behavior was implicated by high productivity of both macrophytes and algae species equation [1].

However in the lacustrine zones organic matter (OM) decomposition process involves both DO consumptions as well as other electron acceptor reactions shown by the general equations $\left[\begin{array}{lll}1 & \& & 2\end{array}\right]$

$$
\begin{aligned}
& \mathrm{CO}_{2}+\mathrm{H}_{2} \mathrm{O} \rightarrow \mathrm{CHO}_{2}+\mathrm{O}_{2}+\Delta \mathrm{H} \\
& \mathrm{CHO}_{2}+\mathrm{O}_{2}+\Delta \mathrm{H} \rightarrow \mathrm{CO}_{2}+\mathrm{H}_{2} \mathrm{O}
\end{aligned}
$$

Such reactions consequently trigger other important redox reactions e.g. the reduction of iron oxides, sulfates and nitrates from the sediments. The production of $\mathrm{CO}_{2}$ from decomposition of $\mathrm{OM}$ has a great influence on the carbonic acid reactions involving carbonates equations [3].

$\mathrm{CO}_{2} \rightarrow \mathrm{HCO}_{3}^{-} \rightarrow \mathrm{CO}_{3}^{2-}$

Presence of high biodiversity in Mindu (macrophytes, fowls, ducks, fishes, snails could plays a primary significant role in the loading of various nutrients through the trophic levels. Concurrently the redirection of $\mathrm{PO}_{4}{ }^{3-}, \mathrm{SO}_{4}{ }^{3-}, \mathrm{Mg}^{2+}$ and $\mathrm{Ca}^{2+}$ is achieved through decompositions and redox reactions in the Reservoir water sediment interfaces.

As the Reservoir lacustrine ecosystems eventually becomes the sink and supplier of the end products of biogeochemical processes; consequently these products controls the geological processes and vice versa (Hecky et. al, 2003; Bootsma and Hecky, 2003; Hecky, 1993; Kilham, 1990; Nduku and Harrison, 1976).

This study furthermore identified sediments as another significant source of $\mathrm{N}$ and $\mathrm{P}$ loading into the water column through internal recycling mechanisms, driven by wind mixing normally experienced in shallow water bodies.

The continuously internal loading of nutrients from sediments into Mindu water column supports both algae and macrophyte's productivity during the dry season. The comparative high concentrations of nitrogen relative to phosphorous in macrophyte infested areas, suggests the supper abundance in blue green algae at the Reservoir surface waters which is common to eutrophic water bodies as was also reported in work by Andre, et. al (2003).

\section{CONCLUSION AND RECOMMENDATIONS}

From the data obtained it was concluded that Mindu Reservoir behaved like the eutrophic shallow alkaline lake whose features suggests a continuous strong interactions, between biota and their geochemical environments. Mindu Reservoir water chemistry and limn logical parameters were greatly influenced by the catchments' climate, hydro geochemical processes and ecology, which were also supported by the hydro chemical ratios, multivariate and bivariate data analyses by Ngonyani (2003). We recommend a more detailed hydro-bio-geo-chemical study preferably for more than one cycle to capture inter seasonal variability both temporal and spatially, for the sequestration of nutrients at various trophic levels. The proposed continuous research study for Mindu Reservoir could be used in the construction of an comprehensive integrated Mindu Resources management program, which will involve all the riparian communities.

\section{ACKNOWLEDGEMENTS}

Sincere appreciation goes to the Head of Soil Science Department at the Sokoine University of Agriculture, for the laboratory work support and the Directorate of the Morogoro Water and Sanitation Authority (MOWASA) for facilitating the acquisition of the necessary data at Mindu Reservoir. I acknowledge the University Of Dar Es Salaam through the faculty of Science of Environmental Sciences and staff for creating space for this research and data analysis.

\section{KEY}

E-site17 East macrophyte infested zone sampling point 17

Fish-L Fish landing/market

Low R-L Lower river line Outlet 
Mid/R-L Middle river line Lacustrine zone

Mlali/MK Mlali and Mkurunge Rivers entry point

Mzinga Mzinga River entry point

NE-ma North East macrophyte infested zone

NE-site6 North East macrophyte infested zone sampling point 6

Ngere Ngerengere River entry point

NW-ma North -West macrophyte infested zone

NW-site5 North West macrophyte infested zone sampling point 5

SE-ma South East macrophyte infested zone

SE-site19 South East macrophyte infested zone sampling point 19

Site8 Middle river line Lacustrine zone sampling point 8

Village-way Vilage way Human habitats and wash area

Site12 Sampling point 12

Site22 Sampling point 22

Site19 Sampling point 19

Site20 Sampling point 20

\section{REFERENCES}

American Public Health Association., (1995), Standard methods for the examination of water and wastewater $19^{\text {th }}$ Ed, APHA Washington DC.

Andre, E. R., Hecky, R. E., and Duthie, H. C., (2003), Nitrogen and phosphorus regeneration by cichlids in the littoral zone of Lake Malawi, Africa. Journal of Great Lakes Research 29(2): 190-201.

Bootsma, H. A., and Hecky, R. E., (2003), A comparative introduction to the biology and limnology of the African Great Lakes. Journal of Great Lakes Research 29(2):3-18.

Davis, J. C., (2002). Statistics and data analysis in Geology. $3^{\text {rd }}$ Ed., John Wiley \& Sons Inc..,New York. 252 pp

Hecky, R. E., (1993), The eutrophication of Lake Victoria. Verh. Int. Vereins. Limnol. 25:3948.

Hecky, R. E., Bootsma, H. A., and Kingdon, M. L., (2003), The importance of river basin characteristics and impact of land use change on sediment and nutrient yields to Lake Malawi/Nyasa (Africa). Journal of Great Lakes Research 29(2):139-158.

Kilham, P., (1990), Mechanism controlling the chemical composition of lakes and rivers: data from Africa. Limnol, Oceanogr, 35: 80 83.

Klute, A., (Ed) (1986), Methods of soil analysis, Part I Physical and mineralogical methods $2^{\text {nd }}$ Edition No. 9 in series Agronomy, American Society of Agronomy Inc, Mudson, Wisconsin USA., 1188 pp.

Mbago, F. M., (1999), Preliminary Botanical Survey of Aquatic Plants of the Mindu Dam, Morogoro Tanzania. Department of Botany University of Dar es Salaam (unpublished).

MOWASA., (2001), The 2001 Aquatic weeds infestations at Mindu dam report by the Morogoro Urban Water Supply and Sewage Authority, (MOWASA)., In Mwananchi (Eds) Tuesday October $3^{\text {rd }}$, 2001, p 6-7 Na 00479).

Nduku, W. K., and Harrison, A. D., (1976), Calcium as a limiting factor in biology of Biomphalaria pfeifferi (Krauss), (Gastropoda: Planorbidae). Hydrobiologia, Vol. 49, 2 p. 143 - 170.

Ngonyani, C. J., (2003), Study of nutrient pollutants and their impacts on the water quality of the Mindu Reservoir in Morogoro Municipality. MSc. Dissertation (Environmental Sciences) of the University of Dar Es salaam pp156 
Rapp, A., Berry, L., and Temple, P., Eds. (1973), Studies of soil Erosion and Sedimentation in Tanzania. Research Monograph Number 1., Bureau of Resources Assessment and Land Use Planning., University of Dar Es salaam, Tanzania p $105-379$.

Sampson, D. N., and Wright, A. E., (1964), The Geology of the Uluguru Mountains Geological Survey of Tanzania, Bulletin No. 37 Government Printer Dar es Salaam 65 pp.
Sibuga, K.P., (1997). Weed management in Eastern and southern Africa: Challenges for $21^{\text {st }}$ Century. Proceeding of the $16^{\text {th }}$ Biennial Weed Science Society Conference for East Africa., Adipale E., Tussime, G. and Okori, Eds. pp 5-11

Verburg, P., and Hecky, R. E., (2003), Wind patterns, evaporation, and related physical variables in Lake Tanganyika East Africa., Journal of Great Lakes Research 29(2):48-61. 